\title{
Szalóki Gergely[1]: Adalékok a római zálogjog továbbéléséhez a középkori germán jogokban
}

Debreceni Jogi Mühely, 2010. évi (VII. évfolyam) 3. szám (2010. október) 47-50.

Az alábbiakban a római és a germán zálogjog alapszerkezetét kívánjuk összehasonlítani, illetve rámutatni arra, hogy a római zálogjog szabályai milyen mértékben hatottak a középkori germán zálogjog szabályaira.

\section{Zálogjog a római jogban}

A római jogban a zálog három fejlődési fokozaton ment át: a fiducia, a pignus és a hypotheca.[2] Mind a három alakzat egyaránt érvényesült mind az ingók, mind az ingatlanok tekintetében.

A fiducia lényege, hogy az adós a zálogtárgy tulajdonjogát formailag a hitelezőre ruházza, de azzal a kikötéssel (pactum fiduciae), hogy teljesítés után a tulajdont reá visszaruházza. [3] A visszaruházást az adós actio fiduiaevel[4] követelheti, ez a kereset azonban csak kötelmi természetü, azaz, ha a hitelező a zálogot a pactum fiduciae[5] megszegésével időközben harmadik személyre ruházta át, az adós nem fordulhatott a harmadik jogszerző ellen, hanem csak kártérítést követelhetett hitelezőjétöl.[6] A kereset alapján való elmarasztalás a hitelező infámiáját vonta maga után, mert bizalmi viszonnyal élt vissza.[7]

A fiduciárius tulajdonátruházás nem járt szükségképpen a zálog átadásával, az adós a záloghitelező beleegyezésével esetleg birtokolhatta a dolgot, de csak szívességi használat jogcímén.[8] A tulajdon átruházása továbbá nem szüntette meg a zálogos jogviszony alapjául szolgáló követelést. Nyilvánvaló, hogy a fiducia intézménye teljes biztonságot eredményezett a hitelező számára, de veszélyeztette az adós érdekeit. Ezen hátrányokat a pignus küszöböli ki.[9]

Míg a fiducia külsőleg a hitelező tulajdonaként jelentkezik,[10] addig a pignus formája a hitelező birtoka. Az adós nem a dolog tulajdonát ruházza át hitelezőjére, hanem csupán birtokát és azt teljesítés után actio pigneratitia directával követelheti vissza.[11] A hitelező nem tulajdonos ugyan, de mindenkivel szemben birtokvédelemben részesül, joga tehát dologi jog.

A pignusnak azt a nagy hátrányát, hogy a dolog birtokát és használatának lehetőségét a zálogos jogviszony tartamára a hitelezőtől elvonja, a hypotheca küszöböli ki.[12] A hypotheca nem jár a dolog átadásával, az adós azt csak leköti a hitelező javára,[13] aki a zálogot a teljesítés elmaradása esetén mindenkivel szemben hatályos keresettel - actio Serviana utilis in rem, actio in rem hypothecaria) követelheti.[14] Ennek a keresetnek a lényege csupán az, hogy a hitelező a zálogtárgy birtokába léphessen, ami által ő a kézizálogos hitelező jogi helyzetébe kerül. Éppen ezért a hypotheca nem más, mint elhalasztott kézizálogjog,[15]szemben a ma is ismert jelzálogjoggal, mely közvetlen kielégítési jogot biztosít a hitelező számára.

A zálogtárgyból való kielégítés módja az idők folyamán jelentős változásokon ment keresztül. Már a fiduciánál is ki lehetett kötni, hogy nemteljesítés esetén a dolog a hitelezö teljes - nem csak formai - tulajdonába menjen át (ez a lex commissoria, melyet utóbb eltiltottak).[16] Ki lehetett tovább kötni, hogy a hitelező a dolog hasznait szedje, és követelésének kielégítésére fordítsa, vagy, hogy a zálogtárgyat eladja (pactum de vendendo pignore, ius distrahendi),[17]és az eladási árból elégítse ki magát. Hasonló mellékszerződések járultak a pignushoz és a hypothecához is. Később az eladási jog külön kikötés nélkül is megillette a hitelezőt, azaz a zálogjog természetes elemévé vált. Később pedig az ellenkező megállapodás 
(pactum de non contrahendo)[18] sem zárja ki az eladási jog gyakorlását, hatálya csupán az, hogy eladás előtt az adóst nem egyszer, hanem háromszor kellett fizetésre felszólítani.

A ius distrahendi jogi természetét tekintve egybehangzó volt a jogtudósok álláspontja, hogy a záloghitelező a zálogtárgy értékesítésekor saját érdekében és saját jogán jár el (in venditione suum creditor negotium gerit, suum ius exsequitur).[19] Bár a ius distrahendi a zálogszerződés alapvető, esszenciális alkotórészévé vált, a római jogban a személyes követelésnek a zálogjogtól való függetlensége mindvégig megmaradt.[20] A zálogjog nem nyeli le az alapul fekvő követelést, a hitelező nem köteles a zálogjogát gyakorolni, tetszésén múlik, hogy a zálogból szerez-e kielégülést vagy adósa ellen fordul; ha a zálog eladási ára nem fedezi a követelést, a kettő között mutatkozó különbözetet a zálog eladása után is követelheti adósától, ellenkező esetben viszont köteles neki a vételár felesleget kiadni.

\section{Zálogjog a germán jogban}

A germán zálog az önhatalmú zálogolásból, a tilosban talált állatok behajtásából fejlődött ki. A károsult eleinte megölhette az elcsatangolt állatot, később már csak a kisebb állatokat, nevezetesen szárnyasokat volt szabad elpusztítani, nagyobb háziállatokat csupán akkor, ha tulajdonosuk meghatározott időn belül nem váltotta ki őket a behajtótól.[21] Az önhatalmú zálogolás szolgált kiinduló pontként a szerződéssel létrehozott zálogjog számára.

A germán jogok alapvető tétele, hogy csupán a zálog felel a tartozásaiért, az adós nem. Ebből következik, hogy ha a dolog a záloghitelező hibáján kívül megsemmisül, a követelés megszünik, másrészt az adós sem követelheti vissza hitelezőjétől azt a különbözetet, amellyel a zálogtárgy értéke a követelést meghaladja.[22] Később szokásossá vált, hogy az adós a zálogszerződés megkötésekor a római stipulatióhoz hasonló adóssági ígéretet tett, ezzel ő személyes kötelezettséget vállalt, reá szállt a vétlen elveszés veszélye, jogot szerzett a zálogtárgy eladásakor befolyó összeggel való elszámolásra, viszont felelős lett a zálogtárgy esetleges hiányaiért is.[23]

Ellentétben a római joggal, az ingók csak kézizálogba voltak adhatóak. Eleinte a háramlási zálogjog volt a jellemző, $[24]$ azonban később az adós ellen indítható személyes kereset a zálogjogtól elkülönült, és a zálogtartót csak ius distrahendi illette meg, a többlettel pedig el kellett számolni.

Az ingatlan zálogjognak három föfajtája különböztethető meg: a tulajdoni (Satzung), a haszonélvezeti és a jelzálog (neue Satzung avagy jüngere Satzung).[25] A tulajdonzálog formája - a római fiduciának megfelelően - a tulajdonátruházás. Ebben az esetben a jogviszony nem egyéb, mint a visszavásárlás jogának kikötésével megkötött adásvétel. Ritkább a felfüggesztő a feltétel, vagyis az a megállapodás, hogy a tulajdonjog csak a teljesítés elmaradása esetén szálljon át a hitelezőre. A birtokba adás egyik esetben sem volt feltétel, a birtokba adás jelképesen megy végbe a tulajdonátruházási okirat átadásával, mely esetben a hitelező ígéretet tesz arra, hogy teljesítés esetén az okiratot visszaszolgáltatja.[26]

A haszonélvezeti zálogjog lényege az, hogy az ingatlan tulajdonjoga az adósnál marad, a hitelező azonban a jószág birtokába lép, és hasznait szedi; ez szolgált kamat gyanánt. Ha a hasznok a kölcsönadott töke kamataihoz képest aránytalanul nagyok, a felek akként is megállapodhattak, hogy a hitelező csak bizonyos hasznokat élvezzen, vagy valamennyi hasznot, de csak meghatározott hozadék erejéig, a többlettel pedig az adós felé el kellett számolnia. Kiköthető volt az is, hogy a hasznok a tőke törlesztésére szolgáljanak.

A haszonélvezeti zálogjog nem járt szükségképpen a birtokátruházásával. Előfordulhatott, hogy az adós, mint bérlő a zálogtárgy birtokában maradt, és a hasznok átengedés helyett bért fizetett a hitelezőnek. Ami a zálogból való kielégítés módját illeti, eleinte az volt a szabály, hogy a teljesítés elmaradása mit sem változtatott a jogviszonyon, a jószág egyszerüen 
továbbra is a hitelező haszonélvezetében maradt, az adós a visszaváltás jogával később is, bármikor élhetett. A visszaváltási jognak határidőhöz való kötése is csupán azzal a hatással járt, hogy, amennyiben eltelt, a zálogtárgy örökké a hitelezőnél maradt de továbbra is zálogképpen (örökzálog). Az örökzálog mellett szokásossá vált a háramlási zálog is, mely azonos volt tulajdonképpen a római lex commissoriával.

A jelzálog (jüngere Satzung) a végrehajtási eljárásból fejlődött ki, főként a városi jogokban.[27]Az ingatlan-végrehajtás rendes módja ugyanis az volt, hogy az adóst elidegenítési és terhelési tilalommal együtt megfosztották a birtoklástól, azután pedig, megfelelö határidő tüzésével, árverésre került sor.[28] A felek azonban még az alapul fekvő megállapodások megkötésekor megállapodhattak akként, hogy a hitelezőt ezen jog a lejáratkor történő nemfizetés esetén megillesse, vagyis, hogy közvetlen kielégítési eljárást kérhessen.[29] Az ilyen megállapodást, éppúgy, mint a vagyontárgy tulajdonának átruházását, bejegyezték a nyilvános könyvekbe, így a hitelezőt megillető zálogjogról mindenki értesülhetett.[30]

A jelzálog tehát sokkal közelebb állt a ma is ismert jelzálogjoghoz, mint a római hypotheca, mivel közvetlen kielégítési joggal járt, szemben az utóbbival, mely a teljesítés elmaradása esetére is csupán a kézizálogos hitelező jogállását biztosítja a hitelező számára. Eleinte a jelzálog esetén sem volt szabad a vagyontárgyat további zálogjogokkal terhelni, ám később ez a korlátozás megszünt, sőt a további terhelések lehetőségéven rejlett ezen jogintézmény legnagyobb gyakorlati értéke.

\section{Következtetések}

Egyes formák hasonlatossága ellenére a római és a germán zálogjog között igen mélyreható különbségek mutatkoztak.[31] A római zálogjog idegen dologbeli jog, tehát a tulajdon korlátozásának kell tekinteni, miközben a germán zálogjog a tulajdonjog lefejtett elemeként jelentkezik. Ennek magyarázata az, hogy a germán felfogás az ingatlanon való jogi uralom lényegét a haszonélvezetben látta, ennél fogva minden, a vagyontárgy haszonélvezetével járó jog, mint amilyen elvben a zálogjog is, a tulajdonjog egy nemének látszott;[32] ez alól a germán jelzálogjog jelentett csupán kivételt. A római jog azonos elbírálás alá veszi az ingatlanokat az ingókkal, nem ismeri az előbbiek tekintetében sem a germán jogra oly jellemző publicitást,[33] viszont lehetővé teszi bizonyos vagyonrészek, sőt akár egész vagyon elzálogosítását, ami a germán felfogástól idegen; a zálogjogot járulékosnak tekinti, míg a germán jog nem. A római jog recepciója mindazonáltal nem szorította ki a germán zálogjogot, a haszonélvezeti zálogot átalakította ugyan, a jelzálogot azonban szinte érintetlenül hagyta, ami azért is érthetö, hisz a római hypotheca a sokkal fejlettebb és praktikusabb jüngere Satzunghoz képest határozott visszalépést jelentett volna.[34]

[1]PhD- hallgató, KRE ÁJK

[2]Brósz Róbert, Pólay Elemér: Római jog, Budapest 1976, 361.; Földi András, Hamza Gábor: A római jog története és institúciói, Budapest 1996, 442.

[3] Carl Georg Bruns: Fontes iuris romani antiqui, Lipcse 1893, 294.; John H. Whitmore: The pledge-idea: a study in comparative legal ideas III, Harvard Law Review, Vol. 11, No. 1 (Apr 25, 1897), 24., 31. sk.

[4]Földi-Hamza 1996, 442. sk.

[5]Willian H. Lloyd: Morgages - The genesis of the lien theory, The Yale Law Journal, Vol 32, No. 3 (Jan. 1923) 233.

[6] Brósz-Pólay 1976, 362.

[7] Zalán Kornél: A régi magyar zálogbirtok és mai jogunk, Pécs 193112.

[8]Brósz-Pólay 1976, 362. 
[9] Wolfgang Kunkel: Hypothesen zur Geschichte des römischen Pfandrechts, in: Zeitschrift für Rechtsgeschichte Romanistische Abteilung 90, 1973, 150skk.

[10] Frank Theisen: Die Sicherungsübereignung und Ihre Römischrechtlichen Grundlagen in der Klassik Betrachtungen des Deutschen Gemeinen Rechts des 19. Jahrhunderts, in: Tijdschrift voor Rechtsgeschiedenis, Volume 69, Numbers 1-2, 1 January 2001, 119skk

[11]Brósz-Pólay 1976, 362. sk.; Földi-Hamza 1996, 443.

[12]Whitmore $1897 \mathrm{c}, 22 \mathrm{skk}$.

[13] Földi-Hamza 1996, 443.

[14]Brósz-Pólay 1976, 364.; Földi-Hamza 1996, 445.

[15]Whitmore 1897c, 24. sk.

[16] Brósz-Pólay 1976, 366.

[17] Brósz-Pólay 1976, 363.

[18] Zalán 1931, 12. sk.

[19]Zalán 1931, 12. skk.

[20] Földi Hamza 1996, 444.

[21]Gabriele Isenberg, Barbara Schlkmann: Die Befestigung der mittelalterlichen Stadt, Köln 1997, 225. skk.

[22]Reinhold Johow: Sachenrecht, 1982, 1444. skk.

[23]Zalán 1931, 14. sk.

[24] A háramlási zálogjog oly módon vonatkozik a zálogtárgyra, hogy az adós nem fizetése esetén a hitelezőt illeti a zálogtárgy az esetleges többlettel (hyperocha) együtt. A háramlási zálogot később a kielégítési zálogjog váltja fel, amely pusztán a hitelezö kártalanítását célozza.

[25]John H. Whitmore: The pledge-idea: a study in comparative legal ideas, Harvard Law Review, Vol. 10, No. 6 (Jan 25, 1897), 341. sk.

[26] Ursula Flossmann: Österreichische Privatrechtsgeschichte, Bécs 2008, 191.

[27]Flossmann 2008, 187. sk.

[28]Reinhold Johow: Sachenrecht, 1982, 1446. sk.

[29]Whitmore 1897a, 336 sk.

[30] Bővebben lásd: Herbert Meyer: Neuere Satzung von Fahrnis und Schiffen: ein Beitrag zur Geschichte des deutschen Pfandrechts, 1903

[31]Whitmore 1897c, 33. skk.

[32] Max Rheinstein: Some fundamental differences in real property ideas of the civil law and the common law systems, The University of Chicago Law Review, vol 3, No. 4 (Jun., 1936), 624. skk.

[33]Flossmann 2008, 189.

[34]Lloyd 1932, 234. 